University of Nebraska - Lincoln

DigitalCommons@University of Nebraska - Lincoln

Electron transfer at the microbe-mineral interface: a grand challenge in biogeochemistry

James K. Fredrickson

Pacific Northwest National Laboratory, jim.fredrickson@pnl.gov

John M. Zachara

Pacific Northwest National Laboratory, john.zachara@pnl.gov

Follow this and additional works at: https://digitalcommons.unl.edu/usdoepub

Part of the Bioresource and Agricultural Engineering Commons

Fredrickson, James K. and Zachara, John M., "Electron transfer at the microbe-mineral interface: a grand challenge in biogeochemistry" (2008). US Department of Energy Publications. 264.

https://digitalcommons.unl.edu/usdoepub/264

This Article is brought to you for free and open access by the U.S. Department of Energy at DigitalCommons@University of Nebraska - Lincoln. It has been accepted for inclusion in US Department of Energy Publications by an authorized administrator of DigitalCommons@University of Nebraska - Lincoln. 


\title{
Electron transfer at the microbe-mineral interface: a grand challenge in biogeochemistry
}

\author{
J. K. FREDRICKSON AND J. M. ZACHARA \\ Pacific Northwest National Laboratory, PO Box 999, Richland, WA 99352, USA
}

\begin{abstract}
The interplay between microorganisms and minerals is a complex and dynamic process that has sculpted the geosphere for nearly the entire history of the Earth. The work of Dr Terry Beveridge and colleagues provided some of the first insights into metal-microbe and mineral-microbe interactions and established a foundation for subsequent detailed investigations of interactions between microorganisms and minerals. Beveridge also envisioned that interdisciplinary approaches and teams would be required to explain how individual microbial cells interact with their immediate environment at nano- or microscopic scales and that through such approaches and using emerging technologies that the details of such interactions would be revealed at the molecular level. With this vision as incentive and inspiration, a multidisciplinary, collaborative team-based investigation was initiated to probe the process of electron transfer (ET) at the microbe-mineral interface. The grand challenge to this team was to address the hypothesis that multiheme c-type cytochromes of dissimilatory metal-reducing bacteria localized to the cell exterior function as the terminal reductases in ET to Fe(III) and Mn(IV) oxides. This question has been the subject of extensive investigation for years, yet the answer has remained elusive. The team involves an integrated group of experimental and computational capabilities at US Department of Energy's Environmental Molecular Sciences Laboratory, a national scientific user facility, as the collaborative focal point. The approach involves a combination of in vitro and in vivo biologic and biogeochemical experiments and computational analyses that, when integrated, provide a conceptual model of the ET process. The resulting conceptual model will be evaluated by integrating and comparing various experimental, i.e. in vitro and in vivo ET kinetics, and theoretical results. Collectively, the grand challenge will provide a detailed view of how organisms engage with mineral surfaces to exchange energy and electron density as required for life function.
\end{abstract}

Received 26 September 2007; accepted 15 February 2008

Corresponding author: J. K. Fredrickson. Tel: 509-376-7063; fax: 509-376-4909; e-mail: jim.fredrickson@pnl.gov.

\section{CHALLENGING TERRAIN: THE MICROBE-MINERAL INTERFACE}

Microbial life has been closely intertwined with the geosphere for the entire history of the Earth. Microorganisms, because of their small size, high surface area to volume ratio and incredibly diverse metabolism, have a tremendous influence on their environment through the transfer of energy and materials across complex biologic-solvent-solid interfaces. Although the microbial 'sculpting' of the geosphere is often evident at large scales over the surface of the planet, the interplay between microbes and geological materials is dominated by processes at the molecular and microscopic scales. The microbemineral interface is a prime example of this interplay and represents a complex, and relatively unexplored domain. Many of the details that are currently known about this domain can be attributed to the collective scientific contributions of Terry Beveridge, his students, and colleagues.

Among the first quantitative descriptions of the interactions between metal ions and bacteria were reports by Beveridge and colleagues investigating the binding of aqueous metal cations to various microorganisms including Bacillus subtilis and Escherichia coli and their specific cellular components (Beveridge \& Murray, 1976, 1980; Beveridge \& Koval, 1981; Beveridge et al., 1982; Hoyle \& Beveridge, 1983; Hoyle \& Beveridge, 1984; Ferris \& Beveridge, 1986; Ferris et al., 1988; Mayers \& Beveridge, 1989; Mera \& Beveridge, 1993). These reports revealed the mechanistic nature of these interactions and led to a number of important conclusions regarding the specificity of binding sites on cells for various types of ions. Recognizing the importance of the binding of metal ions to microbial cells and cell components, Beveridge and colleagues 
subsequently probed the nature of resulting biogenic minerals and the mechanisms by which they formed via a combination of observations and characterization of mineral matter from natural environments, and laboratory-based investigations (Beveridge et al., 1983; Ferris et al., 1986; Ferris et al., 1987; Schultze-Lam \& Beveridge, 1994; Urrutia \& Beveridge, 1994; Schultze-Lam et al., 1996; Thompson et al., 1997; Douglas \& Beveridge, 1998). Collectively, this body of research has demonstrated the importance and bacteria and bacterial surfaces in the formation of many mineral types with often unique properties, and the diagenesis of sediments.

Transmission electron microscopy has been used extensively in geobiology to define the architecture of the cell envelope, the location and nature of the interactions with metal ions, and the structure and composition of associated biominerals. Many of the advances in this area can be directly attributed to the pioneering work conducted by the Beveridge laboratory. These investigations visually revealed, for the first time, the intricate and complex structure of the bacterial cell envelope, and the specific sites and structures where metals bind and minerals nucleate. Electron microscopy (EM) and associated sample preparation techniques were developed and perfected by Terry and colleagues to enable study of these complex systems (Graham \& Beveridge, 1990a,b; Graham et al., 1991; Matias et al., 2003), evolving to the point where the University of Guelph has become a leading institution for EM-based analyses of microbial cell architecture and interactions between microbial cells and metals.

The interfacial region between microorganisms and minerals is dynamic with chemistry and structure determined by interplay and response. The molecular workings and linkages across this complex region remain poorly characterized and the science required for their resolution spans broad fields in biology and the physical sciences. Furthermore, in a colloquium sponsored by the American Academy of Microbiology in 2000, 'Geobiology: Exploring the Interface between the Biosphere and the Geosphere', it was concluded that the 'real action' in geobiology happens at the level of individual cells or groups of cells. In the ensuing report from the colloquium (Nealson \& Ghiorse, 2001), it was emphasized that the details of such processes would only be revealed by observations and measurements made at small scales. New advances in microscopy, such as those pioneered in the Beveridge laboratory at the University of Guelph, spectroscopy, and computational chemistry are providing unprecedented opportunities to probe, characterize, and resolve fundamental biologic and chemical phenomena that occur in this important and unique microscopic domain. Biogeochemical phenomena driven by fundamental biologic and chemical interactions at the microbe-mineral interface are significant to major environmental and geoscience research areas including: rock weathering and soil formation; contaminant fate and transport; environmental mineralogy and surface chemistry; biogeochemical cycling of $\mathrm{C}, \mathrm{Mn}, \mathrm{Fe}$, and other elements; biotransformation of organic and inorganic contaminants; environmental sustainability; enhanced oil recovery; and radioactive waste storage and disposal.

\section{GRAND CHALLENGE CONCEPT}

The William R. Wiley Environmental Molecular Sciences Laboratory (EMSL), a US Department of Energy (DOE) national scientific user facility at Pacific Northwest National Laboratory, initiated a grand challenge research effort in biogeochemistry in 2005 to align with research programs in the Environmental Remediation Sciences (ERSD) and Life Sciences Divisions (LSD) of the DOE's Office of Biological and Environmental Research (BER). The Biogeochemistry Grand Challenge, one of two initiated by EMSL, is a coordinated, multi-investigator research effort focused on resolving a major scientific issue in biogeochemistry not accessible to the single investigator. The science themes, debated and identified by a group of experts at a workshop titled 'Earth-Life Interaction at the Microbe-Mineral Interface', held at the Pacific Northwest National Laboratory (PNNL) from November 46, 2003 in Richland, Washington, were cutting edge research topics with potentially broad impacts. As part of the grand challenge concept, advanced experimental and computational capabilities in EMSL and other DOE user facilities were to be leveraged to resolve complex science issues and questions associated with the grand challenge.

After considerable deliberation with input from a group of experts in the field, including Terry Beveridge, the topic of electron transfer (ET) at the microbe-mineral interface was selected. This process involves interplay between microorganisms and the surface, structural, and physicochemical properties of minerals, with the colligative biogeochemical behavior of the microbe-mineral association being of primary importance. Poorly recognized and understood is the interplay between organisms and solids that occurs via the coupling of the electron and proton transport systems in microorganisms with the surface chemical and bulk electronic properties of the solid. Oxides of $\mathrm{Fe}$ and $\mathrm{Mn}$ are semiconductors with very different band gaps and electrokinetic properties, meaning that they respond differently as electrons and protons are added or withdrawn from their surfaces and structures. Changes in electron density induced by microorganisms may be localized to the surface or structurally dispersed depending on these properties and the size of the mineral particle. Accordingly, the associated mineral phase may modulate bacterial activity in complex fashion through these properties, or through structural rearrangements or surface chemical reactions that dissipate energy or alter electron or proton density. An important facet of this topic is the role of surface and structural defects in the mineral phase that typically represents focal points for reactivity (e.g. (Brown et al., 1999)). These defects may be chemical or physical and often represent microscopic domains in the mineral phase that contain excess 

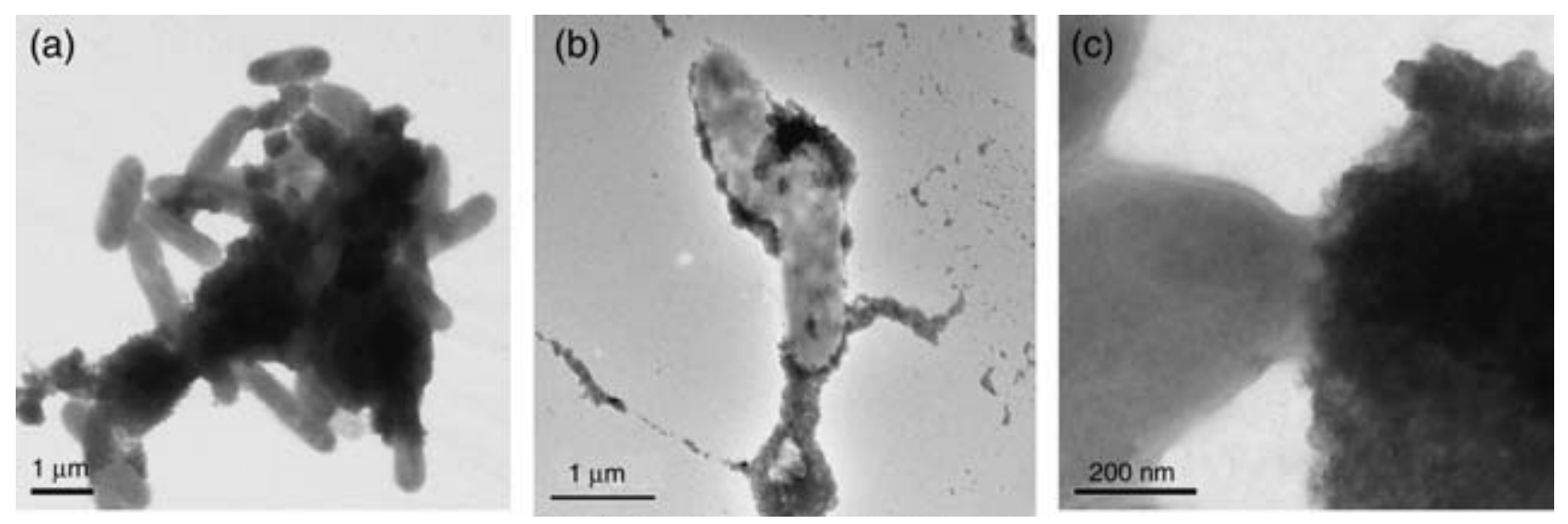

Fig. 1 Transmission electron microscopy images illustrating the interfacial contact between bacteria cells and minerals, specifically the engagement of Shewanella oneidensis MR-1 cells with hydrous ferric oxide (HFO). MR-1 cells rapidly attach to HFO and can form multicellular aggregates in cell-mineral suspensions (a). The engagement of HFO with MR-1 cells is a dynamic process in that with time, other Fe minerals may form as a result of bioreduction and the HFO as well as transformation products can associate with extracellular polymeric substances (EPS, b, c) in addition to being in direct contact with cell surfaces. (Images courtesy of Alice Dohnalkova, Pacific Northwest National Laboratory.)

energy that may be more favorable for microbial exploitation. Alternatively, through their spatially directed microscopic activity, microorganisms may generate defects on or within the mineral phase that alter mineral stability and subsequent reactivity with other system components. Included also in this topic is the important issue of biomineralization. The close spatial association of active bacterial cells with minerals (Fig. 1) creates chemical gradients that drive the formation of new biominerals through recrystallization, solid-state transformation, and/or heterogeneous nucleation (Fredrickson et al., 1998; Zachara et al., 2002), including reactions on mineral surfaces and cell components that serve as templates (Fortin et al., 1997). These oxidative and reductive biomineralization products typically exhibit small particle size and are among the most reactive mineral phases found in the environment.

The biochemical mechanisms by which bacteria exchange electrons with poorly soluble metal oxides have a profound impact on the electron flux from cells to solids and vice versa; bacteria utilize $\mathrm{Fe}$ (III) or $\mathrm{Mn}$ (IV) containing solids as electron acceptors, others may recover energy from structural $\mathrm{Fe}$ (II) or $\mathrm{Mn}(\mathrm{II})$ in mineral solids by enzymatic oxidation, while still others seek structural phosphorous or trace metals to satisfy nutrient requirements. Common to all of these microbiologic processes is the bacterial need to access and react with near-surface and structural ions through microbe-mediated phenomena at the mineral-water interface. Such access may be gained by slow dissolution processes mediated by biogenic organic acids or complexants that facilitate release the target ions (Taillefert et al., 2007), or by chemical transfer between cell surface components and bound, inorganic structural constituents of the mineral medium.

A common tenet in mineral surface chemistry is that structural and chemical defects are focal points for both surface and bulk reaction. Defects may occur as structural vacancies (i.e. where an $\mathrm{O}$ or $\mathrm{Fe}$ is missing in an iron oxide structure), as foreign chemical substituents (i.e. where $\mathrm{Al}^{3+}$ substitutes for $\mathrm{Fe}^{3+}$ in an iron oxide), or as structural discontinuities (e.g. screw, step, or edge dislocations) (see Fig. 2). Defects may occur at the surface or within the bulk, and represent points or regions in the solid where energy is perturbed. Important research questions are whether organisms: (i) exploit the energetic perturbations present in defects to gain access to structural ions needed as energy or nutritional sources, and (ii) generate defects by their own action that regulate the overall biogeochemical behavior of the microbemineral association. Published research has shown striking patterns of bioreductive dissolution on mineral surfaces that contrast with cell-shaped 'footprints' (Rosso et al., 2003) that might be expected from direct contact mechanisms in the absence of electron diffusion within the mineral structure. The dissolution features of haematite observed by Rosso et al. (2003) displayed crystallographic control and alignment with structural defects associated with screw and step dislocations. Implied is the preferential dissolution of high-energy structural regions associated with the defects promoted by a nonlocal ET process, or electron migration to defect sites from the point of biologic ET. Regardless, the mechanisms remain speculative, and resolving them would provide insights into how microorganisms extract energy from complex natural Fe(III) oxides.

Electron transfer between microbial cells and mineral solids is a fundamental process that controls energy exchange throughout the geosphere, yet the mechanisms by which this occurs remain obscure. A prime example is the problem faced by bacterial ET coupled to poorly soluble extracellular electron acceptors such as $\mathrm{Fe}(\mathrm{III})$ and $\mathrm{Mn}$ (III, IV) oxides, as illustrated in Fig. 3, a simplified conceptual model for the dissimilatory metal-reducing bacterium Shewanella oneidensis 


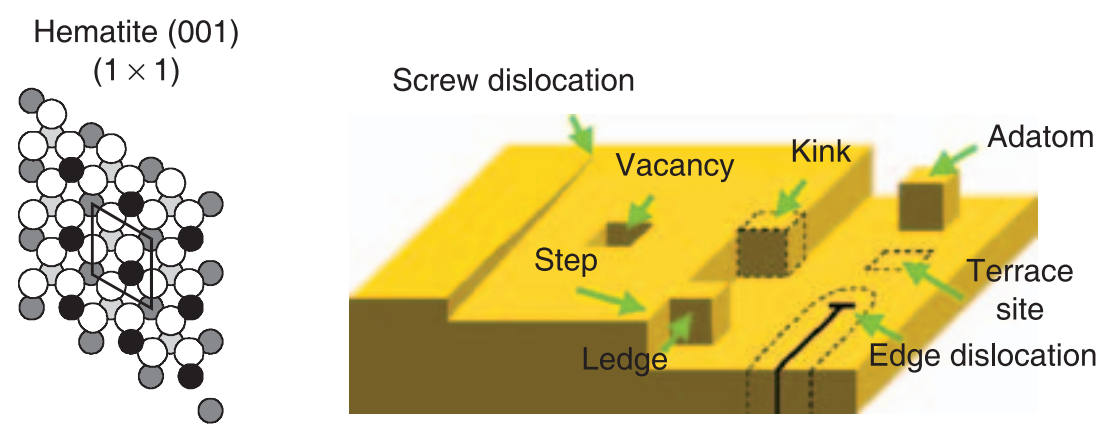

Fig. 2 There are many forms of surface defects in minerals that range in size from subnanometer (vacancies) to micron (structural dislocations in size). These are sites that exhibit different energetic $\mathrm{Fe}^{3+}$ (surface) $\mathrm{Fe}^{3+}$ (bulk) $\mathrm{Fe}^{3+}$ (bulk) Oxygen

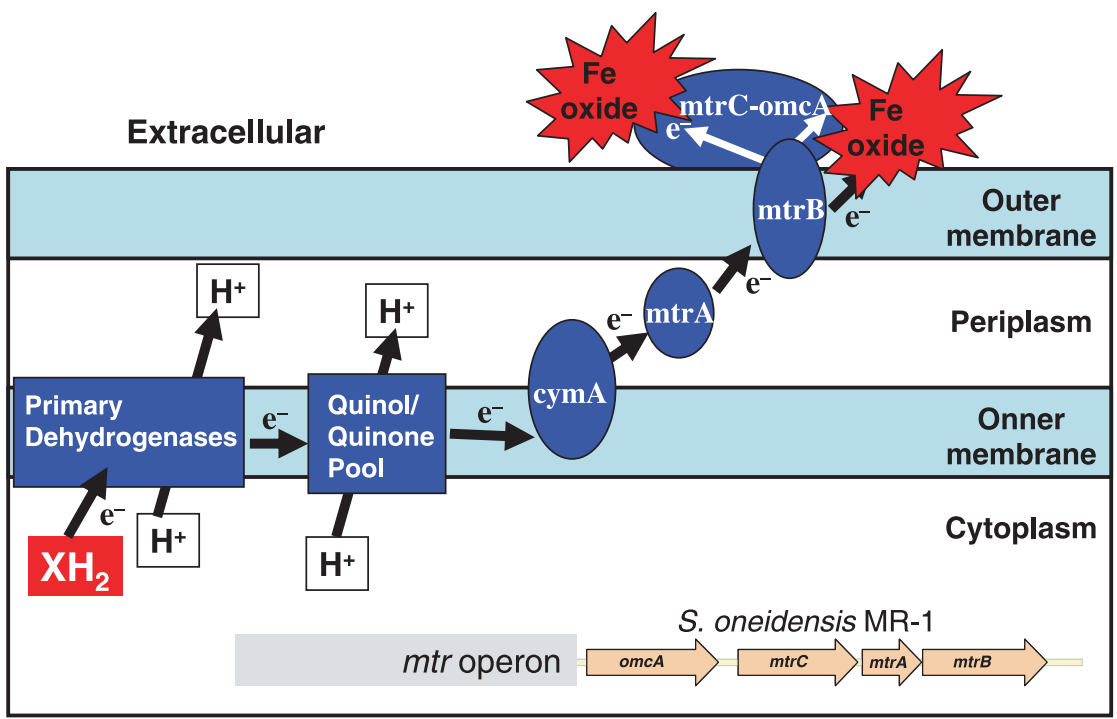

Fig. 3 Model of electron transfer to extracellular $\mathrm{Fe}$ (III) oxides proposed for metal-reducing Shewanella species. Electrons are transferred from primary hydrogenases through an electron transport chain that extends from the cytoplasm and through the inner membrane and quinol pool and subsequently to the tetraheme cytochrome CymA to the periplasm. At this point the electrons are believed to be transferred via the periplasmic decaheme cytochrome MtrA, across the OM via $M$ trB, an integral OM protein, by an unknown mechanism. The terminal electron transfer mechanism is hypothesized to be via outer membrane multiheme cytochromes MtrC and OmcA by a mechanism involving MtrB. (Courtesy of David Richardson, U. of East Anglia.)

MR-1. For respiratory processes involving $\mathrm{O}_{2}$, nitrate, sulfate, or $\mathrm{CO}_{2}$, the substrates freely move across the outer membrane into the periplasm, typically through porins or ion channels, where they engage with various ET proteins. In the case of $\mathrm{Fe}$ and Mn oxides, direct engagement of the periplasmic proteins with $\mathrm{Fe}(\mathrm{III})$ or $\mathrm{Mn}(\mathrm{III}, \mathrm{IV})$ is not possible because these exist as poorly soluble solids external to the cell surface and are unable to pass the outer membrane under most circumstances. Certain bacteria that are proficient at metal oxide reduction appear to have solved this problem by localizing multiheme cytochromes to the exterior of the outer membrane where the proteins can potentially engage directly with oxide surfaces and transfer electrons. Although this is an attractive model, many aspects remain unresolved including the fundamental problem of how electrons are moved from inside the cell to the cell exterior, a process termed solid-state respiration (Nealson \& Little, 1997). Among other mechanisms that may be involved include the biosynthesis of water-soluble organic compounds with electron-donating and -accepting properties that facilitate ET via a shuttle-type mechanism (Newman \& Kolter, 2000), and the biosynthesis of conductive nanowires (Reguera et al., 2005; Gorby et al., 2006). More recently, metal-reducing strains of Shewanella were shown to excrete riboflavin and flavin mononucleotide (FMN) that could function as electron shuttles and accelerate the reduction of poorly crystalline $\mathrm{Fe}(\mathrm{III})$ oxide (von Canstein et al., 2008). These processes are not mutually exclusive and may simultaneously be at play, depending on organism type and environmental conditions. The intent of the biogeochemistry grand challenge was not to broadly address these various mechanisms but rather to focus on evaluating the hypothesis that multiheme cytochromes, implicated in oxide reduction via genetic analyses (Beliaev et al., 2001) and localized to the outer face of the outer membrane in the dissimilatory metal-reducing bacterium Shewanella oneidensis MR-1 (Myers \& Myers, 1992; Myers \& Myers, 2003), can directly transfer 


\section{Hypothesis: Outer membrane cytochromes MtrC/OmcA responsible for direct electron transfer to mineral substrates [Fe, Mn oxides]}

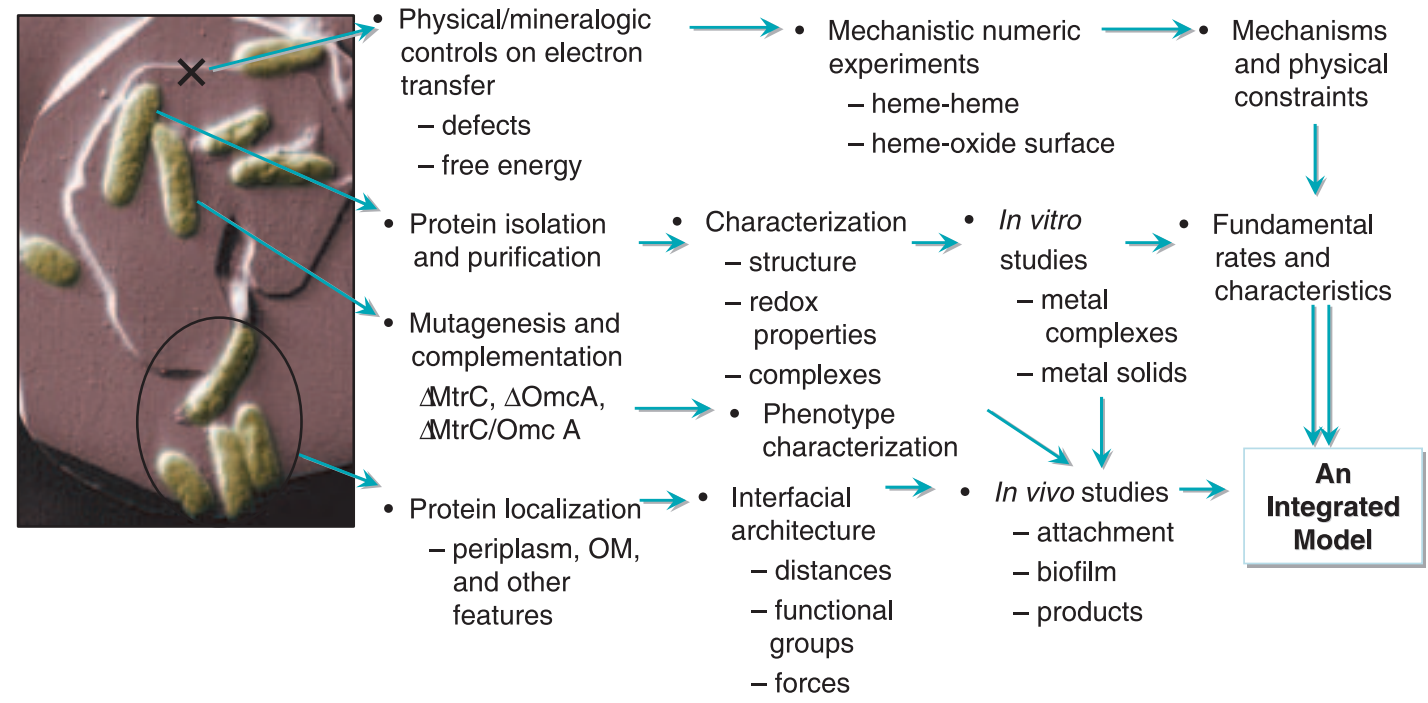

Fig. 4 Technical organization and information flow for the Biogeochemistry Grand Challenge to test the hypothesis that the outer membrane cytochromes MtrC/OmcA in Shewanella oneidensis MR-1 are responsible for direct electron transfer to mineral substrates (Fe, Mn oxides).

electrons to Fe and Mn oxide mineral surfaces. Although the grand challenge was initially focused on dissimilatory metal-reducing bacterium Shewanella, there is evidence to support that this feature is not unique to Shewanella but is likely widespread among other metal-reducing bacteria including Geobacter (Mehta et al., 2005).

\section{INTERDISCIPLINARY APPROACH TO MICROBE-MINERAL ELECTRON TRANSFER}

In a visionary, forward-looking perspective, Terry Beveridge noted that "truly interdisciplinary approaches and teams would be required to explain how individual microbial cells interact with their immediate environment at nano- or submolecular scales' (Beveridge, 2002). To this end, a multidisciplinary approach was developed for the grand challenge to evaluate the hypothesis that the outer membrane cytochromes (OMCs) MtrC (locus tag SO1778) and OmcA (SO1779) in the dissimilatory metal-reducing organism Shewanella oneidensis MR-1 transfer electrons to $\mathrm{Fe}$ and $\mathrm{Mn}$ oxide mineral substrates. The approach involves a combination of in vitro and in vivo biologic and biogeochemical experiments and computational analyses that, when integrated, provide a conceptual model of the ET process (Fig. 4). The in vitro studies involve the purification and characterization of proteins and protein complexes and determination of structural and electrochemical properties by redox titration, scanning tunneling microscopy, thin-film voltammetry on different relevant surfaces, and electron paramagnetic spectroscopy. Experiments with purified proteins have included binding experiments and force measurements to establish mineral-protein interactions and kinetic studies to determine ET rates as well as evaluation of the effect of metal ion structural environment on ET rate. In vivo experiments complement the in vitro studies by establishing the phenotype of specific mutants; probing the location of the OMCs with respect to the cell-mineral interfacial environment; determining the architectural features of the interface including distances, functional groups and biomolecules involved; and by quantifying whole-cell ET kinetics and the apparent governing factors. Numeric experiments and modelling are probing the influence of mineral surface defects, free energy, and electron diffusion within the oxide; and heme orientation, approach distance, and redox potential effects on ET from cytochrome groups to $\mathrm{Fe}(\mathrm{III})$ oxide surfaces (Fig. 5). The resulting conceptual model will be evaluated by integrating and comparing various experimental, i.e. in vitro and in vivo ET kinetics, and theoretical results.

\section{IN VITRO FUNCTIONAL CHARACTERIZATION OF S. ONEIDENSIS MR-1 OMCS}

In vitro $\mathrm{OMC}$ characterization efforts were initiated with the expression, isolation, and purification of MtrC and OmcA from membrane fractions of a $S$. oneidensis MR-1 double mutant lacking endogenous $m t r C$ and $o m c A$ but expressing recombinant, C-terminus-tagged MtrC and OmcA (Shi et al., 2006). The purified proteins were observed to: contain the predicted number of hemes (10); form a high-affinity complex with each other; and rapidly reduce Fe(III)-NTA. Subsequent investigations by Ross et al. (2007) extended these results by 


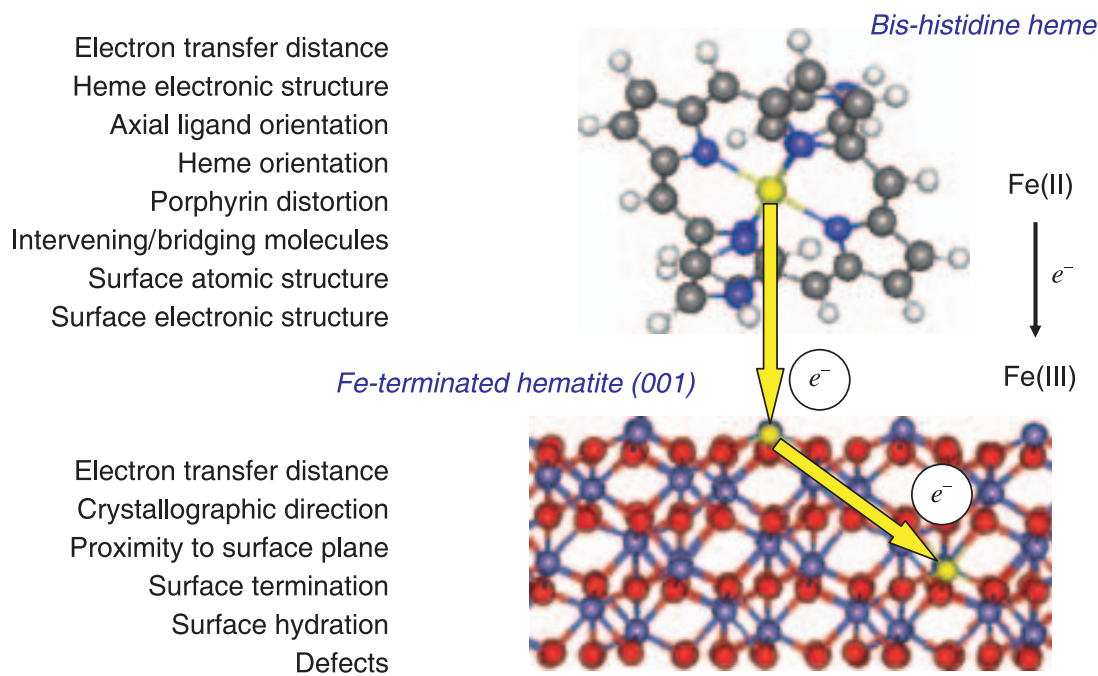

Fig. 5 Factors potentially influencing molecular-scale electron transfer kinetics at the cytochrome/ heme-mineral surface interface and targeted for analysis via numeric experiments. (Courtesy of Sebastien Kerisit and Kevin Rosso, Pacific Northwest National Laboratory.) demonstrating that MtrC, MtrB, and MtrA also co-purify as a functional complex and that MtrC and OmcA are cross-linked by formaldehyde, confirming their physical association. MtrA, another $c$-type cytochrome predicted to be localized to the periplasm, and MtrB, a nonheme integral OM protein, co-migrated through a native gel and were also cross-linked by formaldehyde. MtrB was previously shown to be essential for the reduction of $\mathrm{Fe}(\mathrm{III})$ and $\mathrm{Mn}(\mathrm{IV})$ (Beliaev \& Saffarini, 1998).

Electron transfer between OMCs and their mineral substrates represents a physical challenge to microorganisms because of the strong dependence of ET kinetics on donating heme distance and orientation with respect to the accepting surface plane (Kerisit et al., 2007). In vitro investigations by Xiong et al. (2006) with OmcA and haematite $\left(\mathrm{Fe}_{2} \mathrm{O}_{3}\right)$ nanoparticles $(\sim 11 \mathrm{~nm})$ demonstrated a rapid, high-affinity binding interaction between the purified cytochrome and the mineral concurrent with an electron flux on the order of 0.1 electrons per second per cytochrome. Recombinant MtrC and OmcA covalently linked to a gold substrate through a tetracysteine tag and probed by atomic force microscopy (AFM) with a haematite-functionalized tip, revealed force spectra with unique signatures indicative of specific bonding between each OMC and the haematite surface (Lower et al., 2007), providing further support that the OMCs are capable of direct interaction with metal oxide surfaces (mechanism unspecified). Their comparison of in vitro and in vivo (i.e. whole cell) measurements showed a strong correlation between the various force spectra, allowing the authors to speculate that the unique binding attributes of each OMC are complementary, allowing both proteins to play a role in the transfer of electrons to $\mathrm{Fe}(\mathrm{III})$ mineral surfaces. Optical waveguide lightmode spectroscopy also showed that OmcA adsorbs to isostructural $\mathrm{Al}_{2} \mathrm{O}_{3}$ and $\mathrm{Fe}_{2} \mathrm{O}_{3}$ in similar amounts, and that the adsorption is ionic strength- and pH-dependent (Eggleston et al., 2007). In this same study, electrochemical interaction between adsorbed OmcA and $\mathrm{Fe}_{2} \mathrm{O}_{3}$ was observed using cyclic voltammetry with a haematite electrode. Observed variations in the cathodic peak positions were suggested to result from redoxlinked conformational or molecular orientation changes of the adsorbed cytochrome at the haematite interface.

Ruebush et al. (2006) used total membrane fractions of S. oneidensis MR-1 cells to demonstrate formate-dependent reduction of goethite, haematite, birnessite, and ramsdellite/ pyrolusite. Although these authors did not identify the terminal ET agent(s) associated with the membranes, they did conclude that electron shuttles and iron chelators are not needed for the in vitro reduction of the metal oxides, confirming that reduction can occur by direct contact between the mineral oxides and ET molecules associated with the membranes. Collectively, these results are consistent with previous findings demonstrating that MtrC and OmcA associated with intact cells of $S$. oneidensis MR-1 were degraded by proteinase $\mathrm{K}$ and could be detected by immunofluorescence microscopy, confirming at least a partial cell-surface exposure for these proteins (Myers \& Myers, 2003).

Protein thin-film voltammetry (PFV), used to probe the interfacial redox reactivity of sorbed MtrC on a conductive substrate, revealed facile ET between the cytochrome and the graphite electrode surface and catalytic ET behavior in presence of soluble $\mathrm{Fe}(\mathrm{III})$ complexes (Harthshorne et al., 2007). The hemes within MtrC were observed to titrate over a broad potential from approximately +100 to $-500 \mathrm{mV}$ (SHE), demonstrating thermodynamic power for ET to $\mathrm{Mn}(\mathrm{III} / \mathrm{IV})$ and most $\mathrm{Fe}(\mathrm{III})$ oxides. Electron paramagnetic resonance spectra were consistent with the presence of magnetically spin-coupled, low spin $c$-hemes. These results indicate that the redox and structural properties of MtrC hemes (e.g. alignment, electrostatic environment, and solvent exposure) are compatible with direct, intermolecular electron exchange to solid Fe(III) and Mn(III/IV) surfaces. Scanning tunneling microscopy and tunneling spectroscopy have also 
been used to probe the ET properties of MtrC and OmcA complexed to the $\mathrm{Au}(111)$ surface (Wigginton et al., 2007). Current-voltage TS of individual cytochrome molecules revealed that OmcA and $\mathrm{MtrC}$ have different abilities to mediate tunneling current despite exhibiting some similar biochemical properties suggesting that the two OMCs may have different roles in metal oxide reduction.

Collectively, this experimental and theoretical evidence and other grand challenge results in publication support the hypothesis that MtrC and OmcA can function as the terminal components of an extracellular metal-reduction pathway in S. oneidensis MR-1. These cytochromes exhibit high-affinity binding to a range of mineral and electrode surfaces and engage in rapid ET reactions with them. Despite these significant findings that have clearly contributed to hypothesis resolution, many outstanding scientific issues remain. The details of the biophysical interactions between the OMCs and the electron-accepting surfaces as well as intraprotein ET reactions will ultimately require high-resolution crystal structures to constrain the relative positions of the individual hemes in the context of the overall protein structure, and distances from and alignment with the metal oxide surface. Membrane proteins are particularly challenging in regard to structural characterization and we are unaware of any homologs to the OMCs for which structures are currently available that could be used to gain insight. Research has also revealed that the OMCs are components of a relatively large, complex protein assembly that facilitates ET from the CM, across the periplasm and OM, and ultimately past the LPS to accomplish extracellular ET. The assembly components, at minimum, contain MtrA, MtrB, and the OMCs but are likely to include other components that may be involved in scaffolding and proper localization and positioning within the cell envelope. The nature of these interactions and components of the assembly is likely dynamic, subject to reconfiguration by the cell in response to environmental change. This multiprotein complex may constitute a true molecular 'wire' that facilitates long-distance (e.g. tens of nanometers) ET. In the context of the molecular assembly, we believe that MtrB plays a key role. This protein is known to be essential for $\mathrm{Fe}$ (III) and $\mathrm{Mn}(\mathrm{IV})$ reduction (Beliaev \& Saffarini, 1998), but its function remains poorly understood. Evidence for OMC mislocalization to the inner membrane in an $m t r B$ mutant led to the suggestion that MtrB is involved in the proper insertion of the cytochromes in the OM (Myers \& Myers, 2002). Because of their intimate physical association (Ross et al., 2007), we suggest that MtrB plays a direct role in facilitating ET across the OM, either by providing a conduit for physical contact between MtrA and MtrC/OmcA or by directing electrons across the OM between via an unknown mechanism.

\section{CONCLUDING REMARKS}

The early field and experimental observations by Terry Beveridge and colleagues of microbes interacting with aqueous metal ions, and dissolving and precipitating various types of mineral phases have led to important insights and understandings regarding the underlying mechanisms. With the increasingly sophisticated techniques for probing, at high resolution and sensitivity, the chemical and physical attributes of solids and solutions in combination with the emerging biologic details of microbes being afforded by genomics and new analytical techniques, mechanistic details of microbe-mineral interactions are being revealed. Results generated from the grand challenge are anticipated to lend new insights into other important geomicrobial processes such as the microbial colonization and weathering of basaltic glass, an important rock weathering process on a global basis. The potential energy and nutrients within basalts may also support chemolithotrophic microbial communities in aphotic environments such as the deep terrestrial subsurface (Stevens, 1997). Similar approaches could be applied to develop an understanding of how microbes contribute to the dissolution and precipitation of carbonate minerals that have implications to global carbon budgets, and for biocorrosion, a serious economic problem. With regard to anaerobic corrosion, a Desulfobacterium-like organism was isolated that could reduce sulfate with metallic iron much faster than $\mathrm{H}_{2}$-scavenging sulfate-reducing bacteria such as Desulfovibrio (Dinh et al., 2004). These authors suggested that the efficient use of metallic iron linked to sulfate reduction could be facilitated by direct electron uptake via a cell-surface-associated redox-active component, a process potentially analogous to but in the reverse direction of electron flow from OMCs to metal oxides in some $\mathrm{Fe}$ (III)-reducing bacteria.

The collective investigations of Terry Beveridge and colleagues in the field of geomicrobiology have provided a technical foundation for the 'electron transfer at the microbe-mineral interface' grand challenge. Moreover, Terry Beveridge was a key proponent of the grand challenge concept and served on the advisory committee that helped to identify the science topic. He was also an important technical contributor to tasks focused on protein localization and characterization of interfacial architecture. Terry also served as an inspiration in developing a fully multidisciplinary, integrated approach to this problem and continuously challenged the team to 'think outside the box' and to not become too comfortable with a specific mechanism or interpretation. Finally, we wish to acknowledge Terry as one of the true gentlemen in science. With his quick wit, well-developed sense of humor, and understated recognition of his own accomplishments, he was a pleasure to interact with. We feel privileged to have known Terry both as a colleague and as a friend.

\section{ACKNOWLEDGEMENT}

We would like to thank Alice Dohnalkova, David Richardson, and Kevin Rosso for contributing figures and Sonia Enloe for assistance in preparing this manuscript. The EMSL Scientific 
Grand Challenge project is being performed in part at the W. R. Wiley Environmental Molecular Sciences Laboratory, a national scientific user facility sponsored by the US Department of Energy's Office of Biological and Environmental Research and located at Pacific Northwest National Laboratory (PNNL). PNNL is operated for the Department of Energy by Battelle.

\section{REFERENCES}

Beliaev AS, Saffarini DA (1998) Shewanella putrefaciens mtrB encodes an outer membrane protein required for $\mathrm{Fe}(\mathrm{III})$ and $\mathrm{Mn}(\mathrm{IV})$ reduction. Journal of Bacteriology 180, 6292-6297.

Beliaev AS, Saffarini DA, McLaughlin JL, Hunnicutt D (2001) MtrC, an outer membrane decahaem $c$ cytochrome required for metal reduction in Shewanella putrefaciens MR-1. Molecular Microbiology $39,722-730$

Beveridge TJ (2002) The expanding interdisciplinary nature of environmental microbiology. Environmental Microbiology $\mathbf{4}$, $3-4$.

Beveridge TJ, Koval SF (1981) Binding of metals to cell envelopes of Escherichia coli K-12. Applied and Environmental Microbiology 42, 325-335.

Beveridge TJ, Murray RGE (1976) Uptake and retention of metals by cell walls of Bacillus subtilis. Journal of Bacteriology 127 , 1502-1518.

Beveridge TJ, Murray RGE (1980) Sites of metal deposition in the cell wall of Bacillus subtilis. Journal of Bacteriology 141, 876-887.

Beveridge TJ, Forsberg CW, Doyle RJ (1982) Major sites of metal binding in Bacillus licheniformis walls. Journal of Bacteriology 150, 1438-1448.

Beveridge TJ, Meloche JD, Fyfe WS, Murray RGE (1983) Diagenesis of metals chemically complexed to bacteria: laboratory formation of metal phosphates, sulfides, and organic condensates in artificial sediments. Applied and Environmental Microbiology 45, 1094-1108.

Brown GE, Henrich VE, Casey WH, Clark DL, Eggleston C, Felmy A, Goodman DW, Gratzel M, Maciel G, McCarthy MI, Nealson KH, Sverjensky DA, Toney MF, Zachara JM (1999)

Metal oxide surfaces and their interactions with aqueous solutions and microbial organisms. Chemical Reviews 99, 77-174.

von Canstein H, Ogawa J, Shimuzu S, Lloyd JR (2008) Secretion of flavins by Shewanella species and their role in extracellular electron transfer. Applied and Environmental Microbiology, 10.1128/AEM.01387-07.

Dinh HT, Kuever J, Mussmann M, Hassel AW, Stratmann M, Widdel F (2004) Iron corrosion by novel anaerobic microorganisms. Nature 427, 829-832.

Douglas S, Beveridge TJ (1998) Mineral formation by bacteria in natural microbial communities. FEMS Microbiology Ecology 26, 79-88.

Eggleston CM, Vörös J, Shi L, Lower BH, Droubay TC, Colberg PJS (2007) Binding and direct electrochemistry of OmcA, an outer-membrane cytochrome from an iron-reducing bacterium, with oxide electrodes: a candidate biofuel cell system. Inorganica Chimica Acta, 10.1016/j.ica.2007.07.015.

Ferris FG, Beveridge TJ (1986) Site specificity of metallic ion binding in Escherichia coli K-12 lipopolysaccharide. Canadian Journal of Microbiology 32, 52-55.

Ferris FG, Beveridge TJ, Fyfe WS (1986) Iron silica crystallite nucleation by bacteria in a geothermal sediment. Nature $\mathbf{3 2 0}$, 609-611.

Ferris FG, Fyfe WS, Beveridge TJ (1987) Bacteria as nucleation sites for authigenic minerals in a metal-contaminated lake sediment. Chemical Geology 63, 225-232.

Ferris FG, Fyfe WS, Beveridge TJ (1988) Metallic ion binding by Bacillus subtilis - implications for the fossilization of microorganisms. Geology 16, 149-152.

Fortin D, Ferris FG, Beveridge TJ (1997) Surface-mediated mineral development by bacteria. In Geomicrobiology: Interactions Between Microbes and Minerals (eds Banfield J, Nealson KH), Vol. 35, pp. 161-180. Mineralogical Society of America, Washington, DC.

Fredrickson JK, Zachara JM, Kennedy DW, Dong H, Onstott TC, Hinman NW, Li SW (1998) Biogenic iron mineralization accompanying the dissimilatory reduction of hydrous ferric oxide by a groundwater bacterium. Geochimica et Cosmochimica Acta 62, 3239-3257.

Gorby YA, Yanina S, McLean JS, Rosso KM, Moyles D, Dohnalkova A, Beveridge TJ, Chang IS, Kim BH, Kim KS, Culley DE, Reed SB, Romine MF, Saffarini DA, Hill EA, Shi L, Elias DA, Kennedy DW, Pinchuk G, Watanabe K, Ishii S, Logan B, Nealson KH, Fredrickson JK (2006) Electrically conductive bacterial nanowires produced by Shewanella oneidensis strain MR-1 and other microorganisms. Proceedings of the National Academy of Sciences of the United States of America 103, 11358-11363.

Graham L, Beveridge TJ (1990a) Effect of chemical fixatives on accurate preservation of Escherichia coli and Bacillus substilis structure in cells prepared by freeze-substitution. Journal of Bacteriology 172, 2150-2159.

Graham L, Beveridge TJ (1990b) Evaluation of freeze-substitution and conventional embedding protocols for routine electron microscopic processing of bacteria. Journal of Bacteriology 172, 2141-2149.

Graham LL, Harris R, Villiger W, Beveridge TJ (1991) Freeze substitution of gram-negative eubacteria - general cell morphology and envelope profiles. Journal of Bacteriology 173, 1623-1633.

Harthshorne RS, Jepson BN, Clarke TA, Field SJ, Fredrickson J, Zachara JM, Shi L, Butt JN, Richardson DJ (2007) Characterization of Shewanella oneidensis MtrC: a cell-surface decaheme cytochrome involved in respiratory electron transport to extracellular electron acceptors. Journal of Biology Inorganic Chemistry 12, 1083-1094.

Hoyle B, Beveridge TJ (1983) Binding of metallic ions to the outer membrane of Escherichia coli. Applied and Environmental Microbiology 46, 749-752.

Hoyle BD, Beveridge TJ (1984) Metal binding by the peptidoglycan sacculus of Escherichia coli K-12. Canadian Journal of Microbiology 30, 204-211.

Kerisit SN, Rosso KM, Dupuis M, Valiev M (2007) Molecular computational investigation of electron transfer kinetics across cytochrome-iron oxide interfaces. Journal of Physical Chemistry C $111,11363-11375$

Lower BH, Shi L, Yongsunthon R, Droubay TC, McCready DE, Lower SK (2007) Specific bonds between an iron oxide surface and outer membrane cytochromes MtrC and OmcA from Shewanella oneidensis MR-1. Journal of Bacteriology 189, 4944-4952.

Matias VRF, Al-Amoudi A, Dubochet J, Beveridge TJ (2003) Cryo-transmission electron microscopy of frozen-hydrated sections of Escherichia coli and Pseudomonas aeruginosa. Journal of Bacteriology 185, 6112-6118.

Mayers IT, Beveridge TJ (1989) The sorption of metals to Bacillus subtilis walls from dilute solutions and simulated Hamilton Harbor (Lake Ontario) water. Canadian Journal of Microbiology 35, 764-770.

Mehta T, Coppi MV, Childers SE, Lovley DR (2005) Outer membrane $c$-type cytochromes required for $\mathrm{Fe}(\mathrm{III})$ and $\mathrm{Mn}(\mathrm{IV})$ oxide reduction in Geobacter sulfurreducens. Applied and Environmental Microbiology 71, 8634-8641.

(C) 2008 Pacific Northwest National Laboratory Journal compilation (c) 2008 Blackwell Publishing Ltd 
Mera MU, Beveridge TJ (1993) Mechanism of silicate binding to the bacterial cell wall in Bacillus subtilis. Journal of Bacteriology $\mathbf{1 7 5}$, 1936-1945.

Myers CR, Myers JM (1992) Localization of cytochromes to the outer membrane of anaerobically grown Shewanella putrefaciens MR-1. Journal of Bacteriology 174, 3429-3438.

Myers CR, Myers JM (2002) MtrB is required for proper incorporation of the cytochromes OmcA and OmcB into the outer membrane of Shewanella putrefaciens MR-1. Applied and Environmental Microbiology 68, 5585-5594.

Myers CR, Myers JM (2003) Cell surface exposure of the outer membrane cytochromes of Shewanella oneidensis MR-1. Letters in Applied Microbiology 37, 254-258.

Nealson K, Ghiorse WA (2001) Geobiology: Exploring the Interface between the Biosphere and the Geosphere. American Academy of Microbiology, Washington, DC, p. 23.

Nealson KH, Little B (1997) Breathing manganese and iron: solidstate respiration. Advances in Applied Microbiology 45, 213-239.

Newman DK, Kolter R (2000) A role for excreted quinones in extracellular electron transfer. Nature 405, 94-97.

Reguera G, McCarthy KD, Mehta T, Nicoll JS, Tuominen MT, Lovley DR (2005) Extracellular electron transfer via microbial nanowires. Nature 435, 1098.

Ross DE, Ruebush SS, Brantley SL, Hartshorne RS, Clarke TA, Richardson DJ, Tien M (2007) Characterization of protein-protein interactions involved in iron reduction by Shewanella oneidensis MR-1. Applied and Environmental Microbiology 73, 5797-5808.

Rosso KM, Zachara JM, Fredrickson JK, Gorby YA, Smith SC (2003) Nonlocal bacterial electron transfer to hematite surfaces. Geochimica et Cosmochimica Acta 67, 1081-1087.

Ruebush SS, Icopini GA, Brantley SL, Tien M (2006) In vitro enzymatic reduction kinetics of mineral oxides by membrane fractions from Shewanella oneidensis MR-1. Geochimica et Cosmochimica Acta 70, 56-70.

Schultze-Lam S, Beveridge TJ (1994) Nucleation of celestite and strontianite on a cyanobacterial S-layer. Applied and Environmental Microbiology 60, 447-453.
Schultze-Lam S, Fortin D, Davis BS, Beveridge TJ (1996) Mineralization of bacterial surfaces. Chemical Geology 132, 171-181.

Shi L, Chen BW, Wang ZM, Elias DA, Mayer MU, Gorby YA, Ni S, Lower BH, Kennedy DW, Wunschel DS, Mottaz HM, Marshall MJ, Hill EA, Beliaev AS, Zachara JM, Fredrickson JK, Squier TC (2006) Isolation of a high-affinity functional protein complex between OmcA and MtrC: two outer membrane decaheme $c$-type cytochromes of Shewanella oneidensis MR-1. Journal of Bacteriology 188, 4705-4714.

Stevens T (1997) Lithoautotrophy in the subsurface. FEMS Microbiology Reviews 20, 327-337.

Taillefert M, Beckler JS, Carey E, Burns JL, Fennessey CM, DiChristina TJ (2007) Shewanella putrefaciens produces an $\mathrm{Fe}(\mathrm{III})$-solubilizing organic ligand during anaerobic respiration in insoluble Fe(III) oxides. Journal of Inorganic Biochemistry 101, 1760-1767.

Thompson JB, SchultzeLam S, Beveridge TJ, DesMarais DJ (1997) Whiting events: biogenic origin due to the photosynthetic activity of cyanobacterial picoplankton. Limnology and Oceanography $\mathbf{4 2}$, 133-141.

Urrutia MM, Beveridge TJ (1994) Formation of fine-grained metal and silicate precipitates on a bacterial surface (Bacillus subtilis). Chemical Geology 116, 261-280.

Wigginton NS, Rosso KM, Lower BH, Shi L, Hochella MF Jr (2007) Electron tunneling properties of outer membrane decaheme cytochromes from Shewanella oneidensis. Geochimica et Cosmochimica Acta 71, 543-555.

Xiong Y, Shi L, Chen B, Mayer MU, Lower BH, Londer Y, Bose S, Hochella MF, Fredrickson JK, Squier TC (2006) High-affinity binding and direct electron transfer to solid metals by the Shewanella oneidensis MR-1 outer membrane $c$-type cytochrome OmcA. Journal of the American Chemical Society 128 , 13978-13979.

Zachara JM, Kukkadapu RK, Fredrickson JK, Gorby YA, Smith SC (2002) Biomineralization of poorly crystalline $\mathrm{Fe}(\mathrm{III})$ oxides by dissimilatory metal reducing bacteria (DMRB). Geomicrobiology Journal 19, 179-207. 